\title{
Gender Differences in Carbohydrate Metabolism and Carbohydrate Loading
}

\author{
Jennifer Wismann and Darryn Willoughby \\ Exercise and Biochemical Nutrition Laboratory, Baylor University, Waco, TX. Address correspondence \\ to: Jen_Wismann@baylor.edu
}

Received April 17, 2006/Accepted May 31, 2006

\begin{abstract}
Prior to endurance competition, many endurance athletes participate in a carbohydrate loading regimen in order to help delay the onset of fatigue. The "classic" regimen generally includes an intense glycogen depleting training period of approximately two days followed by a glycogen loading period for 3-4 days, ingesting approximately $60-70 \%$ of total energy intake as carbohydrates, while the newer method does not consist of an intense glycogen depletion protocol. However, recent evidence has indicated that glycogen loading does not occur in the same manner for males and females, thus affecting performance. The scope of this literature review will include a brief description of the role of estradiol in relation to metabolism and gender differences seen in carbohydrate metabolism and loading. Journal of the International Society of Sports Nutrition. $3(1): 28-35,2006$
\end{abstract}

Key words: glycogen loading, estradiol, eummenorrheic

\section{INTRODUCTION}

During bouts of endurance exercise lasting longer than 90 minutes, fatigue generally coincides with low muscle glycogen content, suggesting that simply ingesting carbohydrates during exercise and having glucose available in the blood is not enough to sustain exercise for an extended period of time. This notion led researchers to believe that it may be necessary to load one's body with glucose prior to the long exercise bout ${ }^{1}$. Carbohydrate loading ( $>6$ $\mathrm{g} / \mathrm{kg} / \mathrm{d}$ ) prior to participation in an endurance exercise competition has been shown to help delay the onset of fatigue by approximately $20 \%$ during endurance events lasting longer than 90 minutes ${ }^{2-4}$. One exception to this rule is a study conducted by Burke et al. ${ }^{5}$, where seven trained cyclists ingesting 6-9 $\mathrm{g} / \mathrm{kg} / \mathrm{d}$ of carbohydrate showed no improvement in performance in a 100 kilometer timed trial, despite significantly increased muscle glycogen concentrations.

Nutritional recommendations for endurance athletes directly prior to competition have traditionally included an intense glycogen depleting training period of approximately two days followed by a glycogen loading period for 3-4 days, ingesting approximately $60-70 \%$ of total energy intake as carbohydrates ${ }^{6}$. These recommendations were constructed based on several studies conducted for performance enhancement for this type of athlete ${ }^{7-9}$. However, most of these studies were conducted using only male subjects and the nutritional recommendations have since been used for populations including both males and females. This idea of normality across genders has recently proved to be incorrect as research has shown that there are many metabolic differences between genders that are stemmed from inherent hormonal differences. Specifically, the role of estradiol appears to be the mediator of these metabolic differences and could therefore affect the ability of a female to store, breakdown, and utilize carbohydrates in the same manner as a male ${ }^{10-13}$. The scope of this literature review will include a brief description of the role of estradiol in relation to metabolism and gender differences seen in carbohydrate metabolism and loading.

\section{THE ROLE OF ESTRADIOL IN METABOLISM}

Estradiol primarily serves in development of female secondary sex characteristics. This steroid hormone is secreted cyclically by ovaries, peaking at the time 
of ovulation (see Figure 1) ${ }^{14}$. In addition to assisting with development, estradiol has also been linked with various enzymes that play a role in energy metabolism. Decreased circulating levels of adipocyte lipoprotein lipase (LPL) has been correlated with high estradiol levels ${ }^{15}$, which may result in enhanced triglyceride use in skeletal muscle at varying time points during the menstrual cycle ${ }^{16-}$ 19. Some studies have also shown lipid utilization to be higher during the luteal phase of the menstrual cycle $^{20,21}$. In addition, there is no evidence that indicates variations in muscle glycogen concentrations throughout the menstrual cycle.

\section{CARBOHYDRATE METABOLISM}

Prior to examining gender related differences in carbohydrate loading, gender differences between carbohydrate metabolism must be examined. There appears to be no difference between genders in basal levels of muscle glycogen ${ }^{13,22-24}$, skeletal muscle GLUT- ${ }^{25}$, or hexokinase ${ }^{13}$. However, females do appear to have an enhanced sensitivity to insulin in skeletal muscle ${ }^{19}$, which would theoretically result in increased muscle glycogen storage, as well as enhanced fat storage, but the gender differences in insulin sensitivity are beyond the scope of this paper. In addition, there have yet to be any studies conducted assessing differences in glycogen synthase activity or branching enzyme ${ }^{26}$. Knowledge of changes of these enzymes could assist in the understanding of inherent metabolic differences that exist between genders.

\section{DIFFERENCES IN SUBSTRATE UTILIZATION}

While there appears to be no inherent difference at basal levels of muscle glycogen, there does appear to be a gender related difference in the actual breakdown and metabolism of carbohydrates (Table 1 provides a summary of specific studies). There is evidence that females tend to oxidize less total carbohydrate than men; however, the mechanism behind this phenomenon remains unclear ${ }^{26}$. One possible explanation could be that women have a lower rate of glucose appearance than that of men during endurance exercise ${ }^{27-29}$. Roepstorff et al. ${ }^{29}$ assessed gender differences in substrate utilization during submaximal exercise. Males and females were matched according to peak oxygen consumption $\left(\mathrm{VO}_{2}\right.$ peak) per kg lean body mass, training history, and physical activity level. All females were tested during mid-follicular phase of the menstrual cycle to avoid possible elevated lipid utilization that has been shown during the luteal phase ${ }^{20,21}$. Results of the study showed no gender differences for utilization of fatty acids, blood glucose, and glycogen, and that females oxidized more myocellular triglycerides than males, making up $25 \%$ of total $\mathrm{VO}_{2}$ peak for females and only $5 \%$ of total $\mathrm{VO}_{2}$ peak for males. This indicates that while there were no gender differences in the relative contribution of carbohydrates and lipids, there does seem to be a difference in the utilization of various lipid sources. This coincides with observations seen at rest, indicating greater utilization of fatty acids in the skeletal muscle rather than those derived from the adipose tissue ${ }^{16-19}$.

Tarnopolsky et al. ${ }^{22,23}$ conducted two similar studies evaluating glycogen depletion in the vastus lateralis during endurance exercise. The 1990 study ${ }^{22}$ showed that women had significantly less glycogen depletion than men during treadmill running, but the 1995 study ${ }^{23}$ showed no gender difference in glycogen depletion during submaximal cycling. Despite no difference in glycogen depletion, the study did show that women oxidized significantly more lipid and less carbohydrate and protein compared to men during an exercise bout at $75 \% \mathrm{VO}_{2}$ peak. These data concur with previous observations of greater lipid oxidation of females during submaximal endurance exercise $18,30,31$, but the source of fatty acids differ. It appears as though females tend to utilize more fatty acids from adipose tissue during submaximal exercise, whereas the main source of increased fatty acid utilization at rest is from skeletal muscle ${ }^{16-19}$. Romijin and colleagues ${ }^{32,33}$ also addressed intensity in relation to gender differences in substrate utilization in rats. In both studies, the participants exercised at intensities of 25,65 , and $85 \%$ of $\mathrm{VO}_{2}$ max. The 1993 study ${ }^{32}$ showed that in males muscle triglyceride lipolysis was stimulated only at higher intensities and that at $65 \% \mathrm{VO}_{2}$ max muscle glycogen and triglyceride oxidation decreased. The $2000^{33}$ study showed that in females carbohydrate oxidation increased progressively with exercise intensity, and that the highest rate of fat oxidation was during exercise at $65 \%$ of $\mathrm{VO}_{2} \max$. When comparing the two studies, the authors concluded that after correction for differences in lean body mass, there were no differences between these results and previously reported data in endurance-trained men studied under the same conditions, except for slight differences in glucose metabolism during lowintensity exercise ${ }^{33}$. It is important to note that not all of these studies controlled for variations of lipid metabolism during the menstrual cycle, thus the observed differences between rest and exercise may simply be due to measurement of fatty acid 
utilization during different phases of the menstrual cycle.

Tarnopolsky also assessed glycogen use in the vastus lateralis via muscle biopsy over the course of a 31day endurance cycling training protocol ${ }^{13}$ and found no gender difference in glycogen sparing. A possible explanation of this contradiction with previous literature could be from different muscle recruitment between running and cycling. However, two other studies found that men use more glycogen than women during cycle exercise, but these two studies assessed glycogen use via a stable isotope method rather than muscle biopsy ${ }^{28,34}$.

Horton et al. ${ }^{18}$ conducted a study to assess gender differences in fuel metabolism during long-duration exercise. Fuel oxidation was measured using indirect calorimetry and blood samples were drawn for circulating substrate and hormone levels. Results indicated that females expended more total energy from fat oxidation (50.9\%) than that of men $(43.7 \%)$, but less total energy from carbohydrates $(45.7 \%$ for women and $53.1 \%$ for men). In addition to differences in fuel metabolism, males also had higher circulating levels of catecholamines. These results suggest that females may be more sensitive to the lipolytic actions of catecholamines than men.

\section{EFFECTS OF ESTRADIOL ADMINISTRATION}

With the knowledge that females tend to oxidize a greater amount of fatty acids than males, researchers then assessed the effects of estradiol administration to males. Results indicated that with the addition of 17$\beta$-estradiol to male rats, breakdown of muscle tissue was not diminished during endurance exercise ${ }^{35}$. In fact, administration of $17-\beta$-estradiol to males and oophorectomized female rats resulted in hepatic and muscle glycogen sparing during endurance exercise ${ }^{36}$, increased intramuscular triglyceride content, and decreased adipocyte LPL ${ }^{10}$. Similar results have been observed in human studies with 17- $\beta$-estradiol administration to males ${ }^{37}$ and ammenorrheic females ${ }^{38}$ resulting in a lower rate of glucose disappearance. The addition of 17- $\beta$-estradiol also appears to increase the activity of enzymes in fat oxidation pathways such as carnotine-palmitoyl transferase-1 $(\mathrm{CPT}-1)^{39}$. The role of CPT-1 is to transfer the fatty acyl group from $\mathrm{CoA}$ to carnitine on the cytosolic side of the inner membrane. Enhancement of this pathway allows for greater oxidation of fatty acids in skeletal muscle ${ }^{40}$. Together, these findings suggest that the gender-related differences in carbohydrate metabolism and glycogen use in skeletal muscle may be due to both hepatic glycogen sparing ${ }^{26}$, as well as enhanced muscle triglyceride utilization ${ }^{19}$.

\section{CARBOHYDRATE LOADING}

Increased dietary carbohydrate intake can result in enhanced endurance exercise performance by increasing muscle glycogen stores ${ }^{26}$, but may not in all instances as displayed by Burke et al. ${ }^{5}$ Most of the early studies proving this performance enhancing strategy were conducted with predominantly male subjects ${ }^{7-9}$. The need to assess gender differences with carbohydrate loading and glycogen storage stems from altered glycogen storing ability at different phases of the menstrual cycle ${ }^{41}$ and the influence of estradiol on glycogen utilization ${ }^{11,12,36}$. One of the first studies to evaluate a possible gender difference in glycogen storage after carbohydrate loading was conducted by Tarnopolsky et al. in 1995 ${ }^{23}$. In this study, male and female runners were asked to increase carbohydrate intake for four days, manipulating carbohydrate intake from $55 \%$ to $75 \%$ of total energy intake. The results of the study showed that men increased muscle glycogen content $41 \%$ and improved performance time $45 \%$ following a one-hour cycling bout, whereas women showed no increase in muscle glycogen and improved performance time by only $5 \%$. The authors speculated that a possible reason for this genderrelated difference could be that the increase in dietary carbohydrate intake may not have been enough to elicit glycogen super-compensation. The female participants in this particular study ingested $6.4 \mathrm{~g} / \mathrm{kg}$ body weight of carbohydrate, while the men ingested $8.2 \mathrm{~g} / \mathrm{kg}$ body weight of carbohydrate. However, several studies suggest that there is a "carbohydrate loading threshold," of $8-10 \mathrm{~g} / \mathrm{kg}$ that is necessary to achieve the ergogenic benefits of carbohydrate loading ${ }^{7-9,42}$.

With this knowledge of a "carbohydrate loading threshold," James et al. ${ }^{43}$ also conducted a study to assess these gender differences, but rather than a moderate increase in dietary carbohydrate intake, participants ingested a carbohydrate level of $12 \mathrm{~g} / \mathrm{kg}$ of fat free mass per day. James found that by regulating for fat free mass in conjunction with cessation of daily physical training, women and men were able to achieve similar levels of glycogen supercompensation.

After the "carbohydrate loading threshold" was determined, three other studies ${ }^{13,43,44}$ assessed the loading ability of females at this level of dietary carbohydrate ingestion and found that in order to 
achieve this intake, women would need to increase their total energy intake by $34 \%$ during the carbohydrate loading period. By increasing energy intake $34 \%$, females were able to achieve similar concentrations of glycogen as males, and there were no gender differences in hexokinase activity ${ }^{13}$. However, one study found that even with this increase in carbohydrate ingestion, the females were only able to achieve an increase in glycogen stores that was $50 \%$ of what was observed in males ${ }^{44}$. Therefore, for a female to carbohydrate load and achieve benefits comparable to those of a male, the female must consume extra calories rather than simply increasing the percentage of dietary carbohydrate load. Specifically, a female needs to consume about $30 \%$ more daily energy for four days to ensure that carbohydrate intake achieves levels higher than $8 \mathrm{~g} / \mathrm{kg} / \mathrm{d}^{13}$. For a $55 \mathrm{~kg}$ distance runner, this would be $440 \mathrm{~g}$ of carbohydrate, equaling about 1760 calories daily. If this runner is active and consuming 2500 calories per day, this would represent approximately $70 \%$ of the total daily energy intake from carbohydrate, which is in concurrence with current recommendations, and is only 5\% higher than the 45-65\% American Daily Recommendation for carbohydrate. One possible option that may assist with increased carbohydrate consumption and increased carbohydrate utilization is to employ both a loading method and carbohydrate supplementation prior to competition. Andrews et al. ${ }^{1}$ showed that females used significantly more carbohydrates during submaximal performance following carbohydrate loading and supplementation compared to females who either only supplemented carbohydrates or ingested a placebo. However, the difference in performance time was negligible between three groups.

\section{CONCLUSION AND FUTURE RECOMMENDATIONS}

Despite many questions that remain to be answered in regards to gender differences in carbohydrate metabolism during endurance exercise, it appears as though female athletes do have the capacity for glycogen super-compensation at levels comparable to males when fed comparable amounts of carbohydrates relative to lean body mass ${ }^{43}$. In order to enhance glycogen-storing ability and obtain peak performance from female endurance athletes, it is necessary for future studies to control for menstrual cycle phase. In addition, future studies should assess the influence of estradiol on energy substrate utilization at rest and during various submaximal bouts of endurance exercise in relation to glycogen storage. With this research and knowledge, female athletes could not potentially erase physiological gender differences, but gender differences in performance as well.

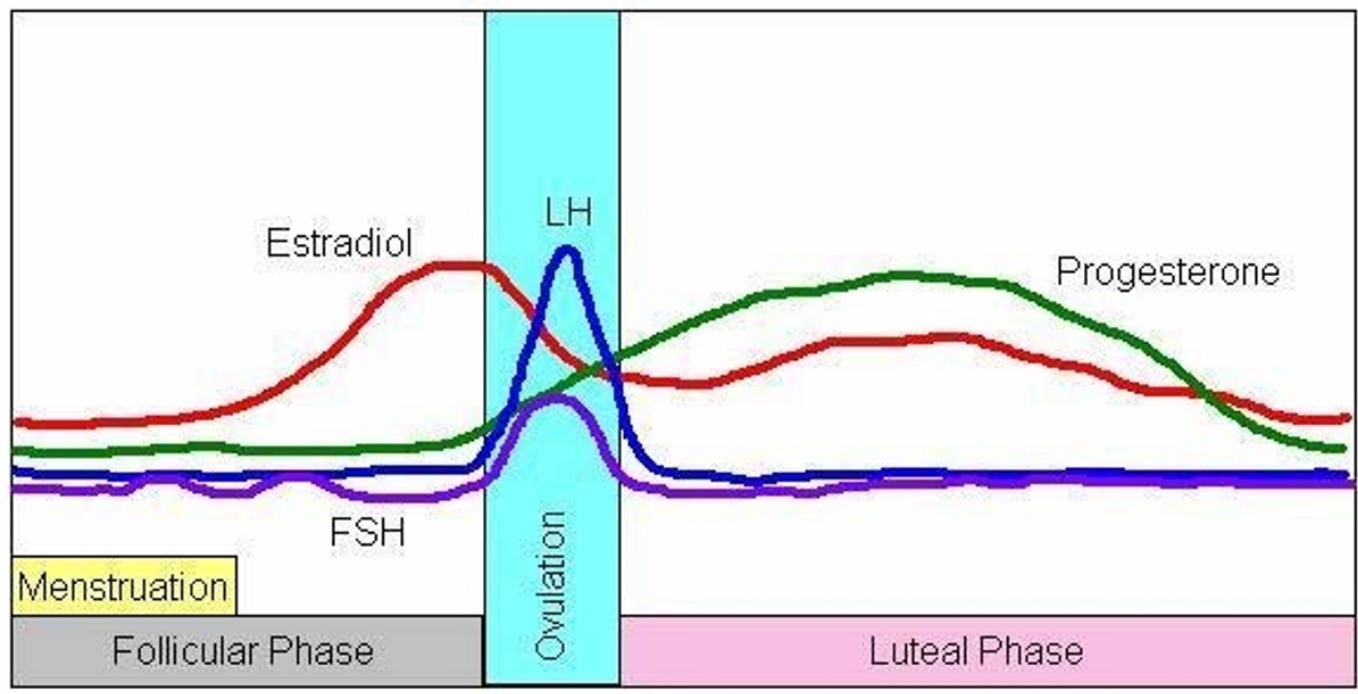

12345678910111213141516171819202122232425262728 Days of Menstrual Cycle

Figure 1: Secretory cycle of female gonadal hormones during a 28-day menstrual cycle. Note the increase in estradiol during the follicular phase just before ovulation, and more even levels during the luteal phase after ovulation. Adapted from wikipedia.org 
Table 1: Articles related to gender differences in substrate utilization

\begin{tabular}{|c|c|c|c|c|}
\hline Author & $\begin{array}{c}\text { Subject } \\
\text { Population }\end{array}$ & Dietary/Hormonal Protocol & Exercise Protocol & Results \\
\hline Friedlander, 1998 & $\begin{array}{l}17 \text { healthy } \\
\text { females }\end{array}$ & \begin{tabular}{|l|} 
Glucose was infused during Two \\
pretraining trials ( 45 and $65 \%$ of \\
VO2 peak) and two posttraining \\
trials [same absolute workload \\
(65\% of old VO2 peak) and same \\
relative workload (65\% of new \\
VO2 peak)
\end{tabular} & $\begin{array}{l}5 \text { days } / \text { wk, } 1 \text {-h } \\
\text { duration, } 75 \% \\
\text { vo2peak }\end{array}$ & $\begin{array}{l}\text { Glucose use is directly related to exercise } \\
\text { intensity; training does reduce total carbohydrate } \\
\text { oxidation }\end{array}$ \\
\hline Carter, 2001 & 8 males & $\begin{array}{l}17 \text { beta-estradiol at } 3 \mathrm{mg} / \mathrm{d} \text { was } \\
\text { administered for } 8 \text { days }\end{array}$ & $\begin{array}{l}90 \text { min cycling } \\
\text { session }\end{array}$ & $\begin{array}{l}\text { Short-term oral } 17 \text { beta-estradiol administration } \\
\text { had no effect on substrate oxidation during } \\
\text { exercise in men. }\end{array}$ \\
\hline Roepstorff, 2002 & $\begin{array}{l}7 \text { males, } 7 \\
\text { females: } \\
\text { endurance } \\
\text { trained }\end{array}$ & None & $\begin{array}{l}90 \mathrm{~min} \text { of bicycle } \\
\text { exercise at } 58 \% \\
\text { VO2peak }\end{array}$ & $\begin{array}{l}\text { In females, measured substrate oxidation } \\
\text { accounted for } 99 \% \text { of the leg oxygen uptake, } \\
\text { whereas in males } 28 \% \text { of leg oxygen uptake was } \\
\text { unaccounted for in terms of measured oxidized } \\
\text { lipid substrates }\end{array}$ \\
\hline Galliven, 1997 & $\begin{array}{l}7 \text { women, } 8 \\
\text { women }\end{array}$ & None & $\begin{array}{l}\text { Study 1: high-intensity } \\
\text { exercise at } 90 \% \\
\text { VO2max; Study 2: } \\
\text { moderate-intensity } \\
\text { exercise at } 70 \% \\
\text { VO2max in the AM } \\
\text { and PM in the follicular } \\
\text { (days } 3-9 \text { ), midcycle } \\
\text { (days 10-16), and } \\
\text { luteal (days 18-26) } \\
\text { phases of the } \\
\text { menstrual cycle }\end{array}$ & $\begin{array}{l}\text { No significant in blood glucose levels; metabolic } \\
\text { and hormonal responses to short-term, high- } \\
\text { intensity exercise can be assessed with equal } \\
\text { reliability in the AM and PM and that there are } \\
\text { subtle differences in blood glucose responses to } \\
\text { moderate-intensity exercise across menstrual } \\
\text { cycle phase }\end{array}$ \\
\hline Hackney, 1994 & 9 women & None & \begin{tabular}{|l|}
$30-$ min treadmill run \\
where intensity was \\
increased every 10 \\
min $(35 \%, 60 \%$, and \\
$75 \%$ VO2peak); tests \\
performed at \\
midfollicular and the \\
midluteal phases of \\
the menstrual cycle
\end{tabular} & $\begin{array}{l}\text { The phase of the menstrual cycle in } \\
\text { eumenorrheic women does influence metabolic } \\
\text { substrate usage during low- to moderate-intensity } \\
\text { submaximal exercise }\end{array}$ \\
\hline Horton, 1998 & $\begin{array}{l}14 \text { men, } 13 \\
\text { women }\end{array}$ & None & $\begin{array}{l}2 \mathrm{~h}(40 \% \text { VO2peak) of } \\
\text { cycling and } 2 \mathrm{~h} \text { of } \\
\text { postexercise recovery }\end{array}$ & $\begin{array}{l}\text { During exercise, women derived proportionally } \\
\text { more of the total energy expended from fat } \\
\text { oxidation, whereas men derived proportionally } \\
\text { more energy from carbohydrate oxidation; } \\
\text { Epinephrine and norepinephrine levels were } \\
\text { greater during exercise in men than in women }\end{array}$ \\
\hline Tarnopolsky, 1995 & $\begin{array}{l}7 \text { males and } 8 \\
\text { females; } \\
\text { endurance } \\
\text { athletes }\end{array}$ & $\begin{array}{l}\text { increase carbohydrate intake } \\
\text { to } 75 \% \text { of daily energy intake for } \\
\text { a period of } 4 \text { days }\end{array}$ & $\begin{array}{l}\text { Cycling at } 75 \% \\
\text { VO2peak } 60 \mathrm{~min}\end{array}$ & $\begin{array}{l}\text { Men increased muscle glycogen concentration } \\
41 \% \text { in response to dietary manipulation and } \\
\text { showed an increase in performance time during } \\
\text { an } 85 \% \text { VO2 peak trial ( } 45 \% \text { ), whereas the } \\
\text { women did not increase glycogen concentration } \\
(0 \%) \text { or performance time ( } 5 \% \text { ); The women } \\
\text { oxidized significantly more lipid and less } \\
\text { carbohydrate and protein compared with the men } \\
\text { during exercise at } 75 \% \text { VO2-peak }\end{array}$ \\
\hline Tarnopolsky, 1990 & $\begin{array}{l}6 \text { males, } 6 \\
\text { females; } \\
\text { endurance } \\
\text { trained }\end{array}$ & None & $\begin{array}{l}\text { Treadmill running at } \\
65 \% \text { VO2peak for } 90- \\
101 \text { min }\end{array}$ & $\begin{array}{l}\text { Males showed greater muscle glycogen } \\
\text { utilization (by } 25 \% \text { ); during moderate-intensity } \\
\text { long-duration exercise, females demonstrate } \\
\text { greater lipid utilization and less carbohydrate and } \\
\text { protein metabolism than equally trained and } \\
\text { nourished males }\end{array}$ \\
\hline Mittendorfer, 2002 & $\begin{array}{l}5 \text { males, } 5 \\
\text { females }\end{array}$ & None & $\begin{array}{l}90 \text { min of moderate- } \\
\text { intensity at } 50 \% \text { VO2 } \\
\text { peak on a cycle } \\
\text { ergometer }\end{array}$ & $\begin{array}{l}\text { Total fatty acid oxidation was similar in men and } \\
\text { women, but the relative contribution of plasma } \\
\text { FFA to total fatty acid oxidation was higher in } \\
\text { women }(76+1-5 \%) \text { than in men }(46+-5 \%)\end{array}$ \\
\hline Tarnopolsky, 2001 & $\begin{array}{l}6 \text { males, } 6 \\
\text { females; } \\
\text { endurance } \\
\text { trained }\end{array}$ & $\begin{array}{l}3 \text { diets: habitual, high } \\
\text { carbohydrate } 75 \% \text { total daily } \\
\text { energy), and carbohydrate + } \\
\text { extra energy ( upward } \\
\text { arrow } 34 \% \text { extra daily caloric } \\
\text { intake)] for a 4-day period }\end{array}$ & None & $\begin{array}{l}\text { Total glycogen concentration was higher for the } \\
\text { men on the high carbohydrate and carbohydrate } \\
+ \text { extra energy trials compared with habitual, } \\
\text { whereas women increased only on the } \\
\text { carbohydrate + extra energy trial compared with } \\
\text { habitual }\end{array}$ \\
\hline Ruby, 2002 & $\begin{array}{l}5 \text { males, } 6 \\
\text { females }\end{array}$ & None & $\begin{array}{l}\text { Cycling for } 25 \text { min at } \\
70 \text { and } 90 \% \text { of } O(2) \\
\text { uptake }(V O(2)) \text { at LT } \\
(70 \text { and } 90 \% \text { LT }\end{array}$ & $\begin{array}{l}\text { No differences between genders in the relative } \\
\text { contribution of carbohydrate (CHO) to total } \\
\text { energy expenditure; the relative contribution of } \\
\text { blood glucose to total } \mathrm{CHO} \text { oxidation was } \\
\text { significantly higher in women }\end{array}$ \\
\hline
\end{tabular}




\section{REFERENCES}

1. Andrews JL, Sedlock DA, Flynn MG, Navalta JW, et al.: Carbohydrate loading and supplementation in endurance-trained women runners. J Appl Physiol 2003. 95: 584-90.

2. Hawley JA, Schabort EJ, Noakes TD, and Dennis SC: Carbohydrate-loading and exercise performance. An update. Sports Med 1997. 24: $73-81$

3. Lambert EV and Goedecke JH: The role of dietary macronutrients in optimizing endurance performance. Curr Sports Med Rep 2003. 2: 194-201.

4. Kiens B: Diet and training in the week before competition. Can J Appl Physiol 2001. 26 Suppl: S56-63.

5. Burke LM, Hawley JA, Schabort EJ, St Clair Gibson A, et al.: Carbohydrate loading failed to improve 100-km cycling performance in a placebo-controlled trial. J Appl Physiol 2000. 88: 1284-90.

6. Brooks GA, Fahey, T.D., White, T.P., \& Baldwin, K.P., Exercise Physiology: Human Bioenergetics and Its Appplications. 3rd ed. 2000, London: Mayfield.

7. Bergstrom J, Hermansen L, Hultman E, and Saltin B: Diet, muscle glycogen and physical performance. Acta Physiol Scand 1967. 71: 140-50.

8. Karlsson J and Saltin B: Diet, muscle glycogen, and endurance performance. J Appl Physiol 1971. 31: 203-6.

9. Sherman WM, Costill DL, Fink WJ, and Miller JM: Effect of exercise-diet manipulation on muscle glycogen and its subsequent utilization during performance. Int J Sports Med 1981. 2: 114-8.

10. Ellis GS, Lanza-Jacoby S, Gow A, and Kendrick ZV: Effects of estradiol on lipoprotein lipase activity and lipid availability in exercised male rats. J Appl Physiol 1994. 77: 209-15.

11. Kendrick ZV and Ellis GS: Effect of estradiol on tissue glycogen metabolism and lipid availability in exercised male rats. $\mathbf{J}$ Appl Physiol 1991. 71: 1694-9.

12. Rooney TP, Kendrick ZV, Carlson J, Ellis GS, et al.: Effect of estradiol on the temporal pattern of exercise-induced tissue glycogen depletion in male rats. J Appl Physiol 1993. 75: 1502-6.

13. Tarnopolsky MA, Zawada C, Richmond LB, Carter S, et al.: Gender differences in carbohydrate loading are related to energy intake. J Appl Physiol 2001. 91: 225-30.

14. Menstrual Cycle. [cited 2006; Available from: http://en.wikipedia.org/wiki/Image:MenstrualCycle.png.

15. Schaefer EJ, Lamon-Fava S, Spiegelman D, Dwyer JT, et al.: Changes in plasma lipoprotein concentrations and composition in response to a low-fat, high-fiber diet are associated with changes in serum estrogen concentrations in premenopausal women. Metabolism 1995. 44: 749-56.

16. Hardman AE: Interaction of physical activity and diet: implications for lipoprotein metabolism. Public Health Nutr 1999. 2: 369-76.

17. Millet L, Barbe P, Lafontan M, Berlan M, et al.: Catecholamine effects on lipolysis and blood flow in human abdominal and femoral adipose tissue. J Appl Physiol 1998. 85: 181-8.

18. Horton TJ, Pagliassotti MJ, Hobbs K, and Hill JO: Fuel metabolism in men and women during and after long-duration exercise. J Appl Physiol 1998. 85: 1823-32.

19. Driskell JA, Wolinsky, I., Energy-Yielding Macronutrients and Energy Metabolism in Sports Nutrition. 2000, Boca Raton: CRC Press.

20. Galliven EA, Singh A, Michelson D, Bina S, et al.: Hormonal and metabolic responses to exercise across time of day and menstrual cycle phase. J Appl Physiol 1997. 83: 1822-31.

21. Hackney AC, McCracken-Compton MA, and Ainsworth B: Substrate responses to submaximal exercise in the midfollicular and midluteal phases of the menstrual cycle. Int J Sport Nutr 1994. 4: 299-308.

22. Tarnopolsky LJ, MacDougall JD, Atkinson SA, Tarnopolsky MA, et al.: Gender differences in substrate for endurance exercise. J Appl Physiol 1990. 68: 302-8.

23. Tarnopolsky MA, Atkinson SA, Phillips SM, and MacDougall JD: Carbohydrate loading and metabolism during exercise in men and women. J Appl Physiol 1995. 78: 1360-8.

24. Lamont LS, McCullough AJ, and Kalhan SC: Gender differences in leucine, but not lysine, kinetics. J Appl Physiol 2001. 91 : 357-62.

25. Hansen PA, McCarthy TJ, Pasia EN, Spina RJ, et al.: Effects of ovariectomy and exercise training on muscle GLUT-4 content and glucose metabolism in rats. J Appl Physiol 1996. 80: 1605-11.

26. Tarnopolsky M: Females and males: Should nutritional recommendations be gender specific? Sportmedizin und Sporttraumatologie 2003. 51: 39-46.

27. Friedlander AL, Casazza GA, Horning MA, Huie MJ, et al.: Training-induced alterations of carbohydrate metabolism in women: women respond differently from men. J Appl Physiol 1998. 85: 1175-86.

28. Carter S, McKenzie S, Mourtzakis M, Mahoney DJ, et al.: Short-term 17beta-estradiol decreases glucose R(a) but not whole body metabolism during endurance exercise. J Appl Physiol 2001. 90: 139-46.

29. Roepstorff C, Steffensen CH, Madsen M, Stallknecht B, et al.: Gender differences in substrate utilization during submaximal exercise in endurance-trained subjects. Am J Physiol Endocrinol Metab 2002. 282: E435-47.

30. Mittendorfer B, Horowitz JF, and Klein S: Effect of gender on lipid kinetics during endurance exercise of moderate intensity in untrained subjects. Am J Physiol Endocrinol Metab 2002. 283: E58-65.

31. Tate CA and Holtz RW: Gender and fat metabolism during exercise: a review. Can J Appl Physiol 1998. 23: 570-82.

32. Romijn JA, Coyle EF, Sidossis LS, Gastaldelli A, et al.: Regulation of endogenous fat and carbohydrate metabolism in relation to exercise intensity and duration. Am J Physiol 1993. 265: E380-91.

33. Romijn JA, Coyle EF, Sidossis LS, Rosenblatt J, et al.: Substrate metabolism during different exercise intensities in endurance-trained women. J Appl Physiol 2000. 88: 1707-14. 
34. Ruby BC, Coggan, A.R., Zderic, T.W.: Gender differences in glucose kinetics and substrate oxidation during exercise near the lactate threshold. J Appl Physiol 2002. 92: 1125-32.

35. Tarnopolsky MA ES, MacDonald JR, Roy BD, MacKenzie S: Short-term 17-beta-estradiol administration does not affect metabolism in young males. Int J Sports Med 2000. 21: 1-6.

36. Kendrick ZV, Steffen CA, Rumsey WL, and Goldberg DI: Effect of estradiol on tissue glycogen metabolism in exercised oophorectomized rats. J Appl Physiol 1987. 63: 492-6.

37. Ruby BC, Robergs RA, Waters DL, Burge M, et al.: Effects of estradiol on substrate turnover during exercise in amenorrheic females. Med Sci Sports Exerc 1997. 29: 1160-9.

38. Carter SL, Rennie CD, Hamilton SJ, and Tarnopolsky: Changes in skeletal muscle in males and females following endurance training. Can J Physiol Pharmacol 2001. 79: 386-92.

39. Campbell SE and Febbraio MA: Effect of ovarian hormones on mitochondrial enzyme activity in the fat oxidation pathway of skeletal muscle. Am J Physiol Endocrinol Metab 2001. 281: E803-8.

40. Borer KT, Exercise Endocrinology. 2003, Champagne: Human Kinetics.

41. Nicklas BJ, Hackney AC, and Sharp RL: The menstrual cycle and exercise: performance, muscle glycogen, and substrate responses. Int J Sports Med 1989. 10: 264-9.

42. Burke LM and Hawley JA: Carbohydrate and exercise. Curr Opin Clin Nutr Metab Care 1999. 2: 515-20.

43. James AP, Lorraine M, Cullen D, Goodman C, et al.: Muscle glycogen supercompensation: absence of a gender-related difference. Eur J Appl Physiol 2001. 85: 533-8.

44. Walker JL, Heigenhauser GJ, Hultman E, and Spriet LL: Dietary carbohydrate, muscle glycogen content, and endurance performance in well-trained women. J Appl Physiol 2000. 88: 2151-8. 